OPEN ACCESS

Edited by:

Lars Pape,

Essen University Hospital, Germany

Reviewed by:

Metin Cetiner,

University of

Duisburg-Essen, Germany

Eugene Yu Hin Chan,

Hong Kong Children Hospital,

Hong Kong, SAR China

*Correspondence:

Yueyi Deng

sh_dengyueyi@163.com

Specialty section:

This article was submitted to

Pediatric Nephrology,

a section of the journal

Frontiers in Pediatrics

Received: 20 June 2021

Accepted: 22 July 2021

Published: 20 August 2021

Citation:

Liu S, Gui C, LU Z, Li H, Fu Z and Deng Y (2021) The Efficacy and Safety

of Rituximab for Childhood

Steroid-Dependent Nephrotic

Syndrome: A Systematic Review and

Meta-Analysis.

Front. Pediatr. 9:728010

doi: 10.3389/fped.2021.728010

\section{The Efficacy and Safety of Rituximab for Childhood Steroid-Dependent Nephrotic Syndrome: A Systematic Review and Meta-Analysis}

\author{
Sidi Liu, Chuying Gui, Zhenzhen Lu, Huijie Li, Zhike Fu and Yueyi Deng* \\ Department of Nephrology, Longhua Hospital, Shanghai University of Traditional Chinese Medicine, Shanghai, China
}

Objectives: Rituximab (RTX), a possible alternative treatment option, is recognized as a new therapeutic hope for the treatment of steroid-dependent nephrotic syndrome (SDNS) in children. However, the efficacy and safety of RTX in the treatment of childhood SDNS are still controversial. The objective of this study was to evaluate the efficacy and safety of RTX treatment in children with SDNS.

Study Design: Six randomized controlled trials (RCTs) and one retrospective comparative control study data from studies, performed before January 2021 were collected, from PubMed, Cochrane Library, Embase, and Web of Science. The studies evaluating the efficacy and safety of RTX in childhood SDNS were included.

Results: Six RCTs and one retrospective comparative control study were included in our analysis. Compared with the control group, the RTX treatment group achieved a higher complete remission rate $(\mathrm{OR}=5.21 ; 95 \% \mathrm{Cl}, 3.18-8.54 ; p<0.00001)$, and we found significant differences between the two groups on serum albumin level (MD $=0.88 ; 95 \%$ $\mathrm{Cl}, 0.43-1.33 ; p=0.0001)$ and estimated glomerular filtration rate $(\mathrm{MD}=6.43 ; 95 \%$ Cl, 2.68-10.19; $p=0.0008$ ). However, RTX treatment did not significantly lower serum creatinine levels nor did it significantly reduce the occurrence of proteinuria. In addition, we found no advantages with RTX on treatment safety.

Conclusions: RTX has shown satisfactory characteristics in terms of efficacy and may be a promising treatment method for SDNS in children. However, the long-term effects have not been fully evaluated and should be further studied through randomized clinical trials.

Keywords: rituximab, childhood steroid-dependent nephrotic syndrome, efficacy, safety, meta-analysis

\section{INTRODUCTION}

Nephrotic syndrome (NS) is a common and multiple glomerular disease in pediatrics. The main clinical features are massive proteinuria, hypoalbuminemia, hyperlipidemia, and edema (1). NS occurs in 16 out of every 100,000 children (2), and it brings greater financial and mental pressure to patients and their families. If it is not controlled in time, serious complications may occur. The development of end-stage renal disease seriously affects the quality of life of children (3). Among them, $75 \%$ of children with NS have minimal change nephropathy, which is sensitive to 
hormone therapy but easily leads to relapse and hormone dependence. Such children often need to extend the hormone medication time or add other immunosuppressants and cellpoisonous drugs (4). Commonly used immunosuppressants include cyclophosphamide, cyclosporine A, tacrolimus, and mycophenolate mofetil. Although the efficacy of these medications is acceptable, their associated adverse events and toxicities would limit their use in long-term maintenance therapy, such as growth and development restriction, weakened immune function, nephrotoxicity, and dyslipidemia (5). Therefore, new drugs are needed to solve these problems.

Rituximab (RTX) is a chimeric monoclonal antibody that targets the transmembrane protein CD20 on B lymphocytes. It was initially effective in the treatment of B-cell lymphoma, and then used to treat diseases like systemic lupus erythematosus, rheumatoid arthritis, and vasculitis (6). In recent years, scholars from many countries have used RTX as a treatment drug for children with NS and have achieved certain effects in treating childhood nephrotic syndrome (7-9). However, the efficacy and safety of RTX for this disease are still controversial, and the mechanism of action and safety in the disease are still unclear. It is still a matter of debate on the treatment of patients with childhood steroid-dependent nephrotic syndrome (SDNS). Thus, we conducted a meta-analysis of the efficacy and safety of RTX in the treatment of childhood SDNS.

\section{METHODS}

\section{Information Sources and Search Strategy}

This meta-analysis was conducted in accordance with the Preferred Reporting Items for Systematic Reviews and MetaAnalyses statement (10). The search strategy was performed in the digital databases of PubMed, Cochrane Library, Embase, and Web of Science from their inception dates to January 2021. Two investigators independently performed a systematic search using the following search terms: "rituximab," "CD20," "children," and "nephrotic syndrome," at the same time, backtracking search for references of related literature.

\section{Study Selection and Data Collection Process}

The initial assessment was based on screening the titles and abstracts; two independent reviewers excluded irrelevant documents based on the inclusion and exclusion criteria. Studies that were not excluded after the initial evaluation were screened in full text, and whether to be included in our analysis was determined according to the inclusion criteria. If there is a disagreement, it is up to the authors to reach a consensus and make the final decision. Case reports, review articles, meeting abstracts, comments, and studies containing mixed pediatric and adult populations without subgroup analysis were excluded.

We extracted patients' outcomes that comprised complete remissions, serum albumin, serum creatinine, proteinuria, eGFR, and related adverse events. Data extraction was done by two independent reviewers, including authors, publication year, country where the study was conducted, study design, sample size, age, sex, interventions, study outcomes, the follow-up, and adverse events, and outcomes with incomplete data were excluded from the analysis.

\section{Bias and Quality Assessments of the Included Studies}

Each quality of the RCT study was assessed according to the "risk of bias" of the Cochrane Collaboration, which includes random sequence generation, allocation concealment, double-blinding, incomplete outcome data, selective reporting, and other bias. Studies that had a high, low, or unclear risk of bias for any of these six components were classified as high or low quality. The quality assessment of the retrospective comparative cohort study was performed using the Newcastle-Ottawa scale.

\section{Statistical Analysis}

Data analyses were performed in Review Manager 5.4 software (version 5.4, The Cochrane Collaboration, The Nordic Cochrane Centre, Copenhagen, Denmark). Continuous variables were analyzed using mean differences (MDs) and 95\% CIs. The Cochrane $Q$ test and the $I^{2}$ statistic were used to analyze the heterogeneity of the included studies, and $p<0.10$ or $I^{2}>50 \%$ represented significant heterogeneity. We used a random effects model for the data analysis ( $Q$-statistic: $P<0.10 ; I^{2}>50 \%$ ), or fixed effects model meta-analyses were performed ( $Q$-statistic: $P$ $\left.>0.10 ; I^{2}<50 \%\right)$. The overall result is statistically significant with a two-sided $p<0.05$.

\section{RESULTS}

\section{Main Results}

A total of 1,047 articles were found in our literature search, including 201 from PubMed, 34 from Cochrane Library, 467 from Web of Science, and 345 from Embase. Using endnote software, 326 repetitive studies were removed. After the selection of titles and abstracts, 658 studies were excluded, and the remaining 63 articles were screened for full text. After screening, seven studies met our inclusion criteria and 56 were excluded, six of which were RCTs (11-16), and one was a retrospective comparative control study (17). The study selection process is shown in Figure 1.

\section{Description of Included Studies Characteristics}

All the seven studies include 446 cases with a mean age of 6-13.6 years. The trials were designed to assess the changes index in complete remissions, serum albumin, serum creatinine, proteinuria, and eGFR. The treatment follow-up period was 1248 months, and most trials included adverse events associated with childhood SDNS. The basic characteristics of the included studies are listed in Table 1. The interventions of treatment groups and control groups are clearly described in Table 2.

\section{The Quality of the Studies}

The risk of bias in each RCT study was assessed by investigating random sequence generation, allocation concealment, blinding, integrity of outcome data, and the possibility of selective reporting (Figures 2A,B). The Newcastle-Ottawa scale scores 


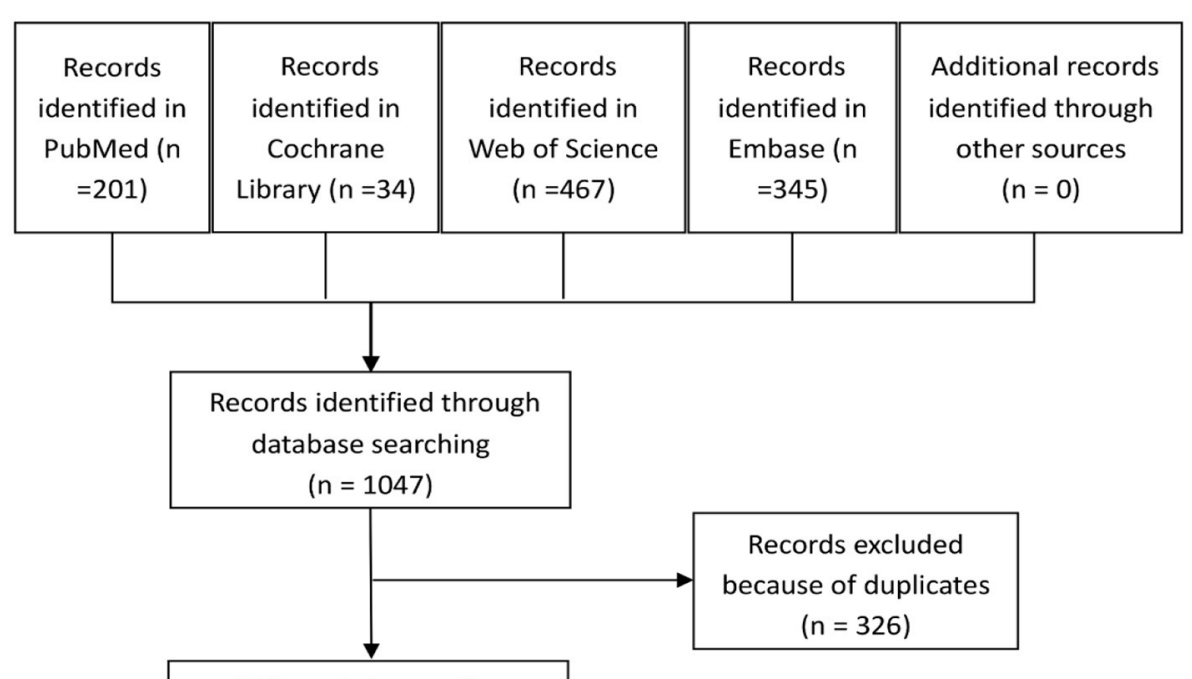

Title and abstract for eligibility ( $n=721$ )

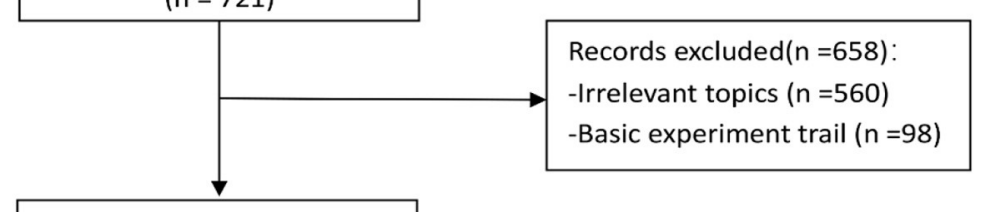

Full text studies

( $n=63$ )

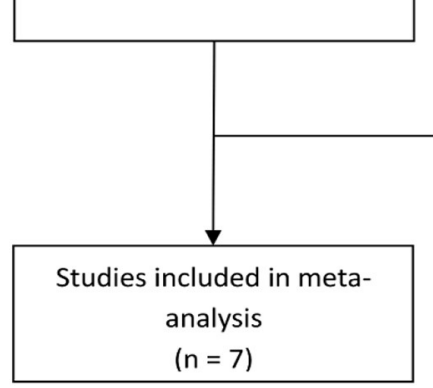

Excluded records $(n=56)$ :

-Case report $(n=8)$

-Reviews ( $n=11$ )

-Inappropriate population $(n=37)$

FIGURE 1 | Flowchart of the studies included.

awarded seven stars for a retrospective comparative control study reported by Sinha A (17).

\section{Efficacy of RTX in Childhood Steroid-Dependent Nephrotic Syndrome Complete Remission Rate}

Six studies reported the complete remission rates. The pooled data from these six studies indicate that RTX treatment group have a higher complete remission rate than control group $(\mathrm{OR}=$ 5.21; 95\% CI, 3.18-8.54; $p<0.00001$ ) appears in Figure 3.

\section{Serum Albumin}

Three studies evaluated the results of serum albumin index (MD $=0.88 ; 95 \%$ CI, $0.43-1.33 ; p=0.0001 ; I^{2}$ of $62 \%$ indicating heterogeneity) (Figure 4). Compared with the control group, RTX group had higher value of serum albumin.

\section{Serum Creatinine}

Sinha A 2012 reported the result of serum creatinine and there was no significant difference between the two groups $(\mathrm{MD}=$ $-0.01 ; 95 \%$ CI, -0.14 to $0.12 ; p=0.88)$, as shown in Figure 5 .

\section{Proteinuria}

Two studies evaluated the results of proteinuria level, and there was no significant difference between the two groups $(\mathrm{MD}=$ -1.00 ; $95 \% \mathrm{CI},-2.56$ to $0.55 ; p=0.21 ; I^{2}$ of $95 \%$ indicating heterogeneity), as shown in Figure 6. 
TABLE 1 | Characteristics of studies included.

\begin{tabular}{|c|c|c|c|c|c|c|c|c|}
\hline References & $\begin{array}{l}\text { Year, } \\
\text { country }\end{array}$ & Study design & Group & Number & $\begin{array}{c}\text { Age } \\
\text { (years) }\end{array}$ & $\begin{array}{c}\text { Sex } \\
\text { (male/female) }\end{array}$ & $\begin{array}{l}\text { The } \\
\text { follow-up } \\
\text { (months) }\end{array}$ & Event \\
\hline Ahn et al. (11) & $\begin{array}{l}2018, \\
\text { Korea }\end{array}$ & Multicenter RCT & $\begin{array}{l}\text { RTX } \\
\text { Control }\end{array}$ & 3516 & $\begin{array}{l}13.5(5.0) \\
12.5(4.2)\end{array}$ & $\begin{array}{l}26 / 9 \\
13 / 3\end{array}$ & 12 & $\begin{array}{l}\text { Infusion reactions, such as } \\
\text { chest discomfort, fever, } \\
\text { vomiting, or skin rash }\end{array}$ \\
\hline Basu et al. (12) & $\begin{array}{l}\text { 2018, } \\
\text { India }\end{array}$ & $\begin{array}{l}\text { Single-center, } \\
\text { parallel RCT }\end{array}$ & $\begin{array}{l}\text { RTX } \\
\text { Control }\end{array}$ & 6060 & $\begin{array}{l}7.1(2.8) \\
7.2(2.8)\end{array}$ & $\begin{array}{l}32 / 28 \\
32 / 28\end{array}$ & 12 & $\begin{array}{l}\text { Mild and transient transfusion } \\
\text { reactions }\end{array}$ \\
\hline lijima et al. (13) & $\begin{array}{l}\text { 2014, } \\
\text { Japan }\end{array}$ & $\begin{array}{l}\text { Multicenter, } \\
\text { double-blind RCT }\end{array}$ & $\begin{array}{l}\text { RTX } \\
\text { Control }\end{array}$ & 2424 & $\begin{array}{l}11.5(5.0) \\
13.6(6.9)\end{array}$ & $\begin{array}{l}18 / 6 \\
16 / 8\end{array}$ & 12 & $\begin{array}{l}\text { Hypoproteinemia, } \\
\text { lymphocytopenia, and } \\
\text { neutropenia }\end{array}$ \\
\hline Ravani et al. (14) & $\begin{array}{l}2011 \\
\text { Italy }\end{array}$ & $\begin{array}{l}\text { Single-center, } \\
\text { parallel RCT }\end{array}$ & $\begin{array}{l}\text { RTX } \\
\text { Control }\end{array}$ & 2727 & $\begin{array}{l}10.2(4.0) \\
11.3(4.3)\end{array}$ & $\begin{array}{l}24 / 3 \\
19 / 8\end{array}$ & 12 & $\begin{array}{l}\text { Bronchospasm, hypotension, } \\
\text { skin rash, and acute arthritis }\end{array}$ \\
\hline Ravani et al. (15) & $\begin{array}{l}2020 \\
\text { Italy }\end{array}$ & $\mathrm{RCT}$ & $\begin{array}{l}\text { RTX } \\
\text { Control }\end{array}$ & 1515 & $\begin{array}{l}7.4(2.6) \\
6.0(3.6)\end{array}$ & $\begin{array}{c}9 / 6 \\
12 / 3\end{array}$ & 48 & $\begin{array}{l}\text { Minimal skin rash and acute } \\
\text { arthritis }\end{array}$ \\
\hline Sinha et al. (17) & $\begin{array}{l}2012 \\
\text { India }\end{array}$ & $\begin{array}{l}\text { Retrospective } \\
\text { control } \\
\text { comparative }\end{array}$ & $\begin{array}{l}\text { RTX } \\
\text { Control }\end{array}$ & 1013 & $\begin{array}{l}12.2(2.3) \\
12.3(3.0)\end{array}$ & $\begin{array}{c}8 / 2 \\
10 / 3\end{array}$ & 12 & $\begin{array}{l}\text { Infusion reactions in the form } \\
\text { of chills, myalgia, and } \\
\text { transient skin rash }\end{array}$ \\
\hline Solomon et al. (16) & $\begin{array}{l}2019 \\
\text { UK }\end{array}$ & $\begin{array}{l}\text { Single-center, } 2 \\
\text { parallel-arm RCT }\end{array}$ & $\begin{array}{l}\text { RTX } \\
\text { Control }\end{array}$ & 6060 & - & - & 12 & - \\
\hline
\end{tabular}

TABLE 2 | Interventions of studies included.

\begin{tabular}{|c|c|c|}
\hline References & $\begin{array}{l}\text { Year, } \\
\text { country }\end{array}$ & Interventions \\
\hline Ahn et al. (11) & $\begin{array}{l}2018, \\
\text { Korea }\end{array}$ & $\begin{array}{l}\text { Treatment group: (1) A single dose of intravenous RTX ( } 375 \mathrm{mg} / \mathrm{m}^{2} \text {; maximum of } 500 \mathrm{mg} \text { ); (2) steroids; and (3) calcineurin inhibitors. } \\
\text { Control group: (1) steroids and (2) calcineurin inhibitors. } \\
\text { (As long as remission was maintained, oral corticosteroids were reduced to } 40 \mathrm{mg} / \mathrm{m}^{2} \text { administered every other day for } 4 \text { weeks and } \\
\text { then tapered by } 25 \% \text { every } 4 \text { weeks for } 3 \text { months, followed by calcineurin inhibitor tapering by } 25 \% \text { every } 4 \text { weeks). }\end{array}$ \\
\hline Basu et al. (12) & $\begin{array}{l}\text { 2018, } \\
\text { India }\end{array}$ & $\begin{array}{l}\left.\text { Treatment group: (1) RTX two to four infusions at weekly intervals ( } 375 \mathrm{mg} / \mathrm{m}^{2} \text {, maximum dose, } 500 \mathrm{mg}\right) \text { and (2) prednisolone. } \\
\text { Control group: (1) tacrolimus }(0.2 \mathrm{mg} / \mathrm{kg} / \text { day, targeting trough levels of } 5 \text { to } 7 \mathrm{ng} / \mathrm{ml}) \text { and (2) prednisolone. }\end{array}$ \\
\hline lijima et al. (13) & $\begin{array}{l}2014, \\
\text { Japan }\end{array}$ & $\begin{array}{l}\text { Treatment group: (1) RTX an intravenous dose of } 375 \mathrm{mg} / \mathrm{m}^{2} \text { (maximum } 500 \mathrm{mg} \text { ) once weekly for } 4 \text { weeks; (2) methyl prednisolone; } \\
\text { (3) acetaminophen; and (4) d-chlorpheniramine maleate. } \\
\text { Control group: (1) prednisolone } 60 \mathrm{mg} / \mathrm{m}^{2} \text { orally } 3 \text { times a day (maximum of } 80 \mathrm{mg} / \text { day) for } 4 \text { weeks, and then tapered over } 6 \text { weeks. }\end{array}$ \\
\hline Ravani et al. (14) & $\begin{array}{l}2011, \\
\text { Italy }\end{array}$ & $\begin{array}{l}\text { Treatment group: (1) RTX (1 or } 2 \text { infusion of } 375 \mathrm{mg} / \mathrm{m}^{2} \text { ); (2) intravenous chlorfenamine maleate; (3) methyl prednisolone; (4) oral } \\
\text { paracetamol; (5) prednisone was tapered off by } 0.3 \mathrm{mg} / \mathrm{kg} \text { per week if proteinuria was }<1 \mathrm{~g} / \text { day; and (6) calcineurin inhibitors. } \\
\text { Control group: (1) prednisone and calcineurin Inhibitors (doses of these agents could be tapered off as in the intervention strategy if } \\
\text { proteinuria was }<1 \mathrm{~g} / \text { day). }\end{array}$ \\
\hline Ravani et al. (15) & $\begin{array}{l}\text { 2020, } \\
\text { Italy }\end{array}$ & $\begin{array}{l}\left.\text { Treatment group: (1) RTX (1 infusion of } 375 \mathrm{mg} / \mathrm{m}^{2}\right) \text {; (2) intravenous chlorfenamine maleate; (3) methyl prednisolone; (4) oral } \\
\text { paracetamol; (5) prednisone (tapered off by } 0.3 \mathrm{mg} / \mathrm{kg} / \text { week starting at } 30 \text { days and withdrawn if proteinuria levels were still }<1 \\
\mathrm{~g} / \mathrm{m}^{2} / \text { day). } \\
\text { Control group: (1) prednisone (tapered off by } 0.3 \mathrm{mg} / \mathrm{kg} / \text { week starting at } 30 \text { days and withdrawn if proteinuria levels were still } \\
<1 \mathrm{~g} / \mathrm{m}^{2} / \text { day). }\end{array}$ \\
\hline Sinha et al. (17) & $\begin{array}{l}2012 \\
\text { India }\end{array}$ & $\begin{array}{l}\text { Treatment group: (1) RTX ( } 2 \text { or } 3 \text { infusions of } 375 \mathrm{mg} / \mathrm{m}^{2} \text { ); (2) tacrolimus (oral at a dose of } 0.1-0.2 \mathrm{mg} / \mathrm{kg} / \mathrm{day} \text { in } 2 \text { divided doses for } \\
12 \text { months; (3) prednisolone ( } 1.5 \mathrm{mg} / \mathrm{kg} \text { on alternate days for } 4 \text { weeks, then reduced by } 0.25 \mathrm{mg} / \mathrm{kg} \text { every } 2-4 \mathrm{weeks} \text { ). } \\
\text { Control group: (1) tacrolimus (oral at a dose of } 0.1-0.2 \mathrm{mg} / \mathrm{kg} / \text { day in } 2 \text { divided doses for } 12 \mathrm{months} \text {; (2) prednisolone (1.5 mg/kg on } \\
\text { alternate days for } 4 \text { weeks, then reduced by } 0.25 \mathrm{mg} / \mathrm{kg} \text { every } 2-4 \text { weeks). }\end{array}$ \\
\hline Solomon et al. (16) & $\begin{array}{l}2019, \\
\text { UK }\end{array}$ & $\begin{array}{l}\text { Treatment group: (1) RTX } 2 \text { to } 4 \text { infusions (1/week, dose } 375 \mathrm{mg} / \mathrm{m}^{2} \text {, maximum } 500 \mathrm{mg} \text { ), until B-cell depletion and (2) prednisolone. } \\
\text { Control group: (1) tacrolimus: } 0.2 \mathrm{mg} / \mathrm{kg} / \text { day (target trough levels of } 5-7 \mathrm{ng} / \mathrm{ml} \text { ) and (2) prednisolone. } \\
\text { (Both arms had tapering doses of alternate-day prednisolone over } 12 \mathrm{months} \text { ). }\end{array}$ \\
\hline
\end{tabular}

\section{eGFR}

Three studies reported the results of eGFR (MD $=6.43 ; 95 \% \mathrm{CI}, 2.68-10.19 ; p=0.0008 ; I^{2}$ of $0 \%$ indicating no heterogeneity) (Figure 7). Compared with the control group, RTX group had higher value of eGFR.

\section{Safety} Infections

Three studies reported the infections $(\mathrm{OR}=1.58$; 95\% CI, 0.25 $10.07 ; p=0.63 ; I^{2}$ of $81 \%$ indicating heterogeneity) (Figure 8), and no significant differences were observed in the occurrence rate of infections between the two groups. 

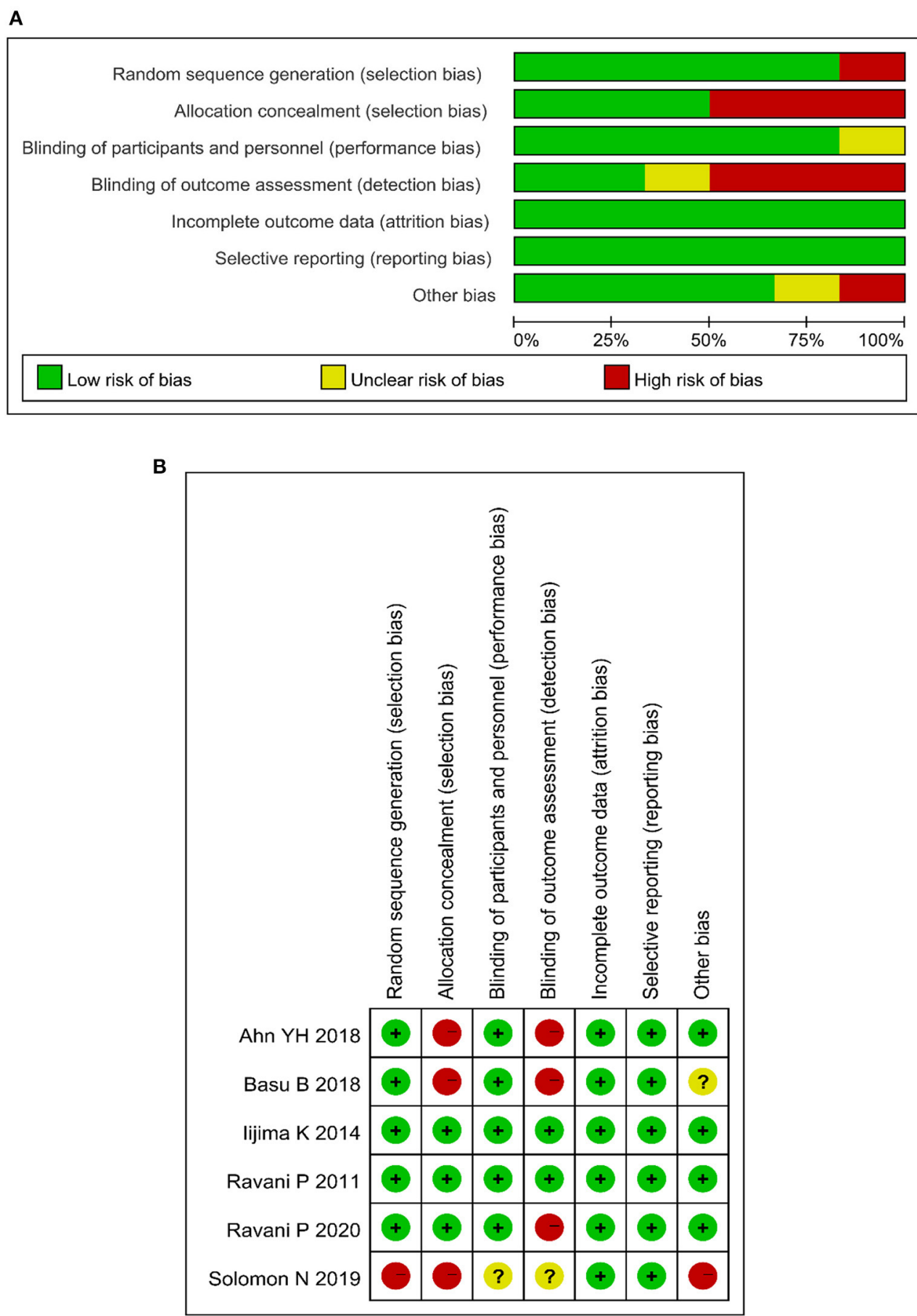

FIGURE 2 | (A) Risk of bias graph. (B) Risk of bias summary.

\section{Infusion Reactions}

Iijima et al. (13) reported the results of infusion reaction events $(\mathrm{OR}=3.22 ; 95 \%$ CI, $0.90-11.46 ; \quad p=0.07)$ (Figure 9), and no significant differences were observed in the occurrence rate of infusion reactions between the two groups.

\section{Cardiovascular Disease Events}

Two studies reported the results of cardiovascular disease events $\left(\mathrm{OR}=1.30 ; 95 \% \mathrm{CI}, 0.31-5.44 ; p=0.72 ; I^{2}\right.$ of $0 \%$ indicating no heterogeneity) (Figure 10), and no significant differences were observed in the occurrence rate of cardiovascular disease events between the two groups. 


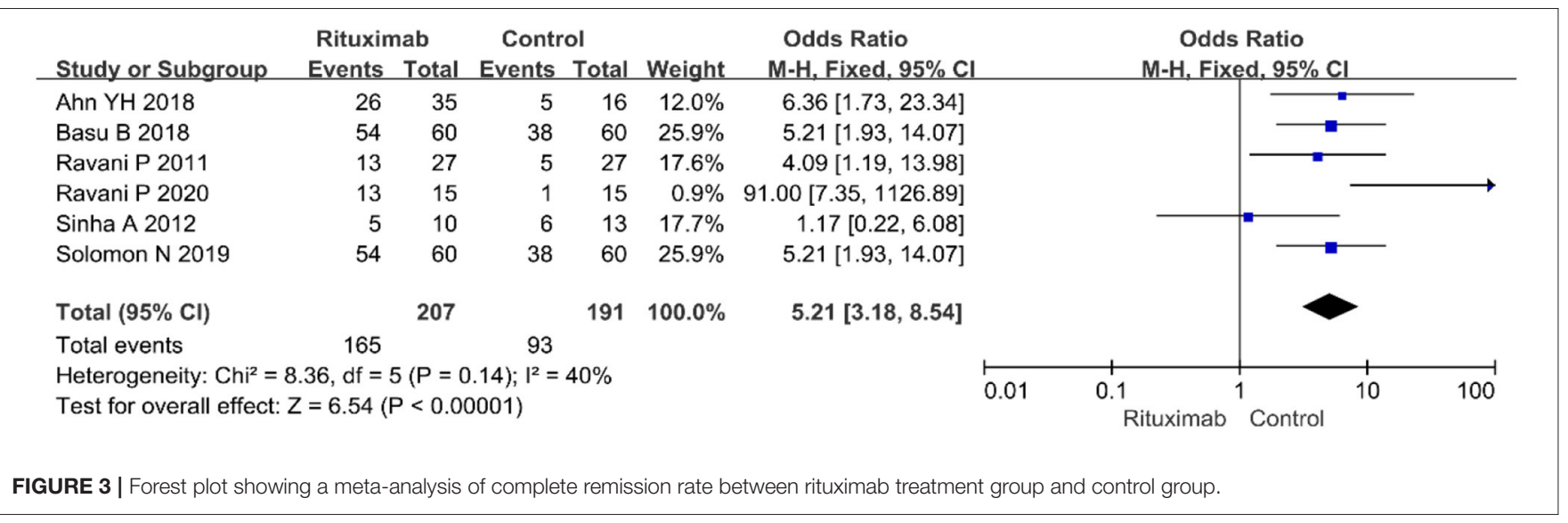

\begin{tabular}{|c|c|c|c|c|c|c|c|c|c|c|c|c|c|}
\hline \multirow{3}{*}{ Study or Subgroup } & \multicolumn{3}{|c|}{ Rituximab } & \multicolumn{2}{|c|}{ Control } & \multirow{2}{*}{ Total } & & \multirow{2}{*}{$\begin{array}{l}\text { Mean Difference } \\
\text { IV. Random, } 95 \% \mathrm{Cl}\end{array}$} & \multicolumn{5}{|c|}{ Mean Difference } \\
\hline & Mean & SD & Total & Mean & SD & & Weight & & & IV. Rando & m. $95 \%$ C & & \\
\hline & 3.4 & 0.7 & 35 & 2.1 & 0.8 & 16 & $35.7 \%$ & $1.30[0.84,1.76]$ & & & p & & \\
\hline Basu B 2018 & 5.63 & 0.99 & 60 & 4.87 & 0.78 & 60 & $43.8 \%$ & $0.76[0.44,1.08]$ & & & $T$ & & \\
\hline Sinha A 2012 & 3.8 & 0.6 & 10 & 3.4 & 1.3 & 13 & $20.5 \%$ & $0.40[-0.40,1.20]$ & & & ф & & \\
\hline Total $(95 \% \mathrm{Cl})$ & & & 105 & & & 89 & $100.0 \%$ & $0.88[0.43,1.33]$ & & & & & \\
\hline \multicolumn{8}{|c|}{$\begin{array}{l}\text { Heterogeneity: } \text { Tau }^{2}=0.10 ; \mathrm{Chi}^{2}=5.20, \mathrm{df}=2(P=0.07) ;\left.\right|^{2}=62 \% \\
\text { Test for overall effect: } Z=3.80(P=0.0001)\end{array}$} & & -100 & -50 Rituximab & Control & 50 & 100 \\
\hline
\end{tabular}

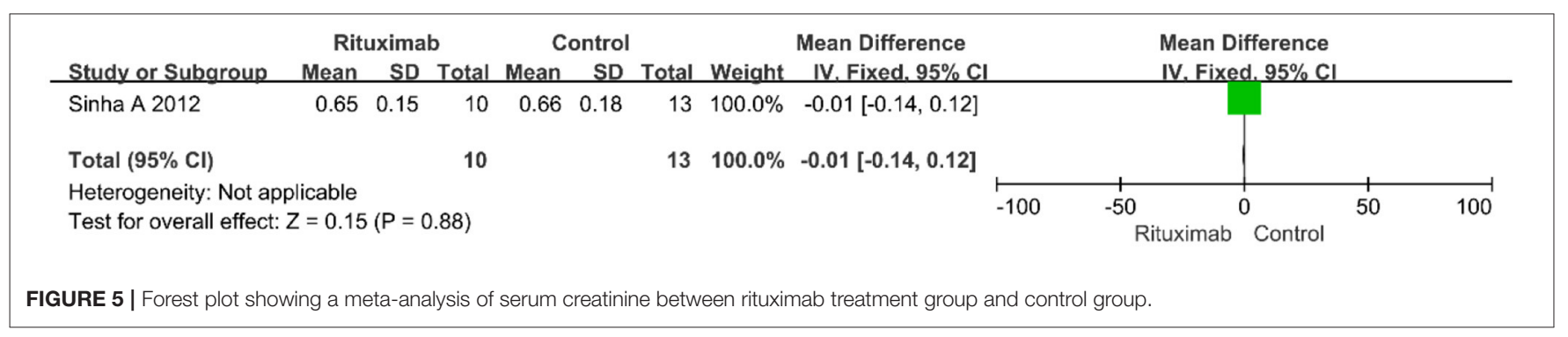

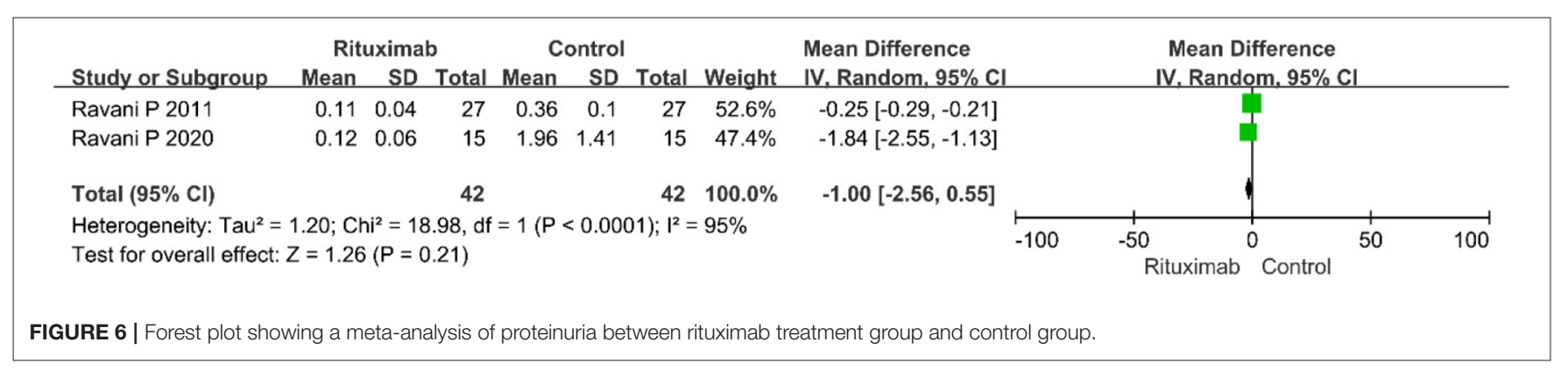

\section{DISCUSSION}

Our meta-analysis included six RCTs and one retrospective comparative control study, involving a total of 446 patients, including 231 in the rituximab group and 215 in the control group. Data analysis results showed that compared with the control group, the RTX treatment group can significantly improve the complete remission rate of children with SDNS. In addition, the RTX treatment group is better than the control group in improving the level of serum albumin and estimated glomerular filtration rate, and the difference is statistically significant. The results 


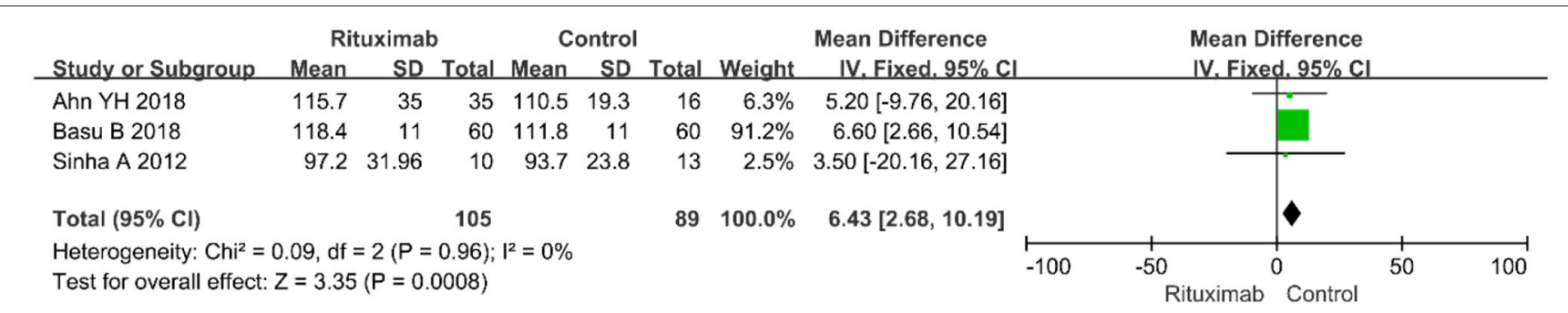

FIGURE 7 | Forest plot showing a meta-analysis of eGFR between rituximab treatment group and control group.

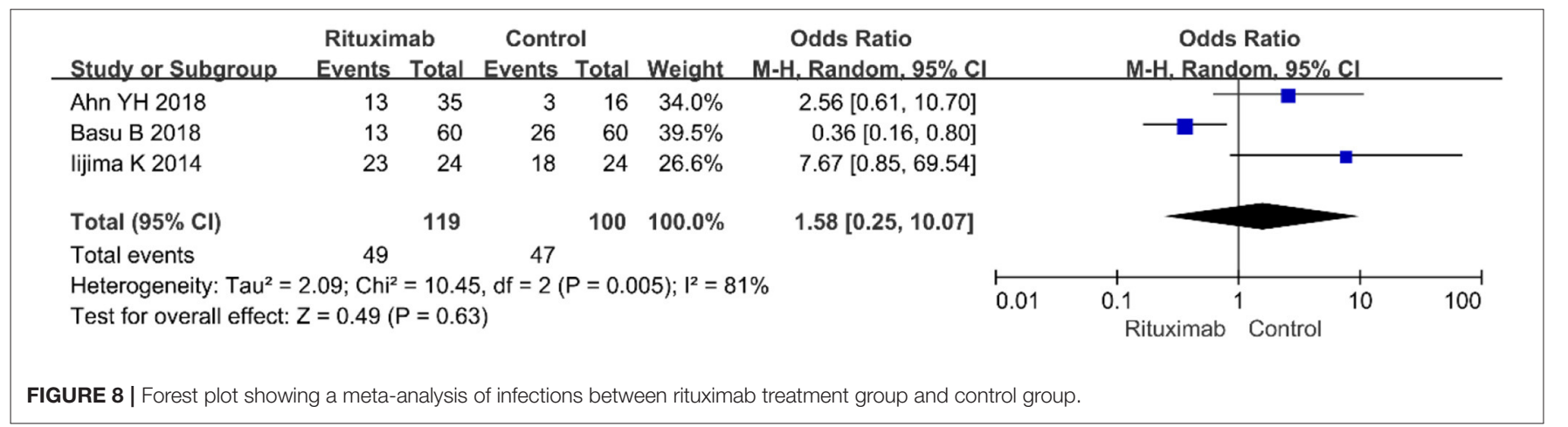

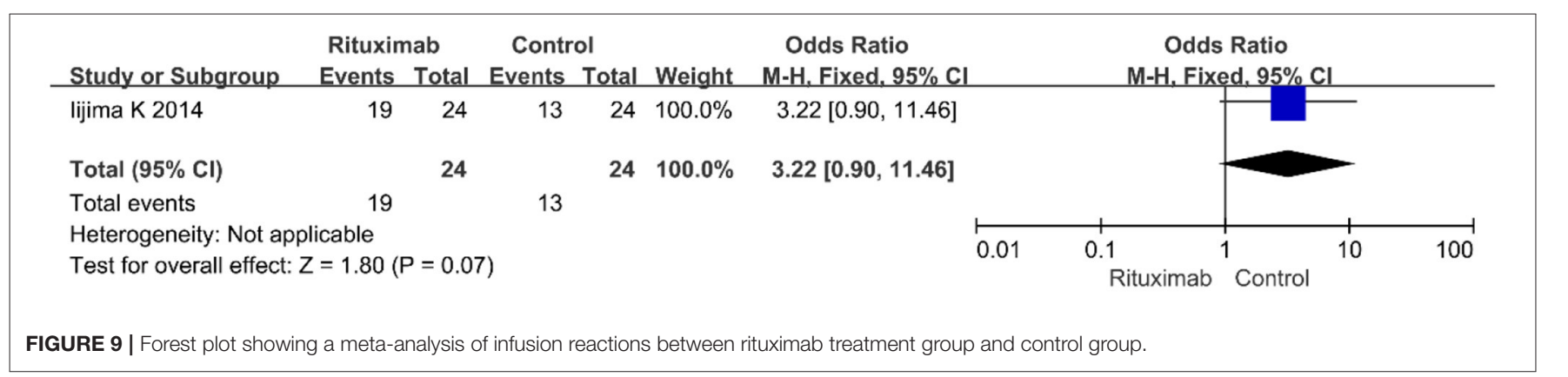

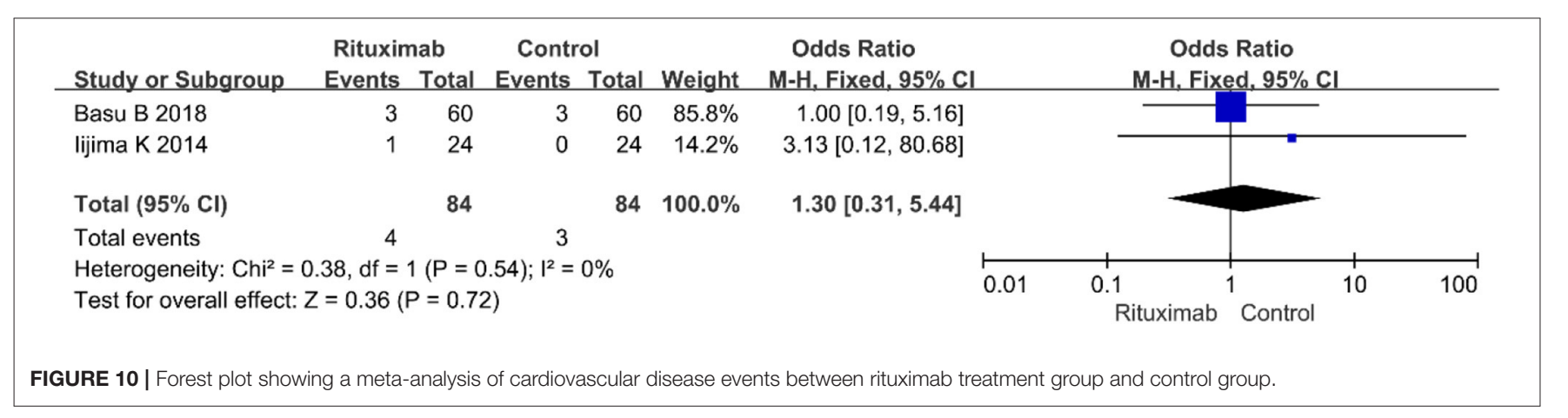

also suggest that the RTX treatment group had a better outcome in reducing the occurrence of proteinuria than the control group, but the difference is not statistically significant. There were no significant differences in serum creatinine levels and related adverse events between the two groups.
The conventional view is that disproportion, activity alterations, and regulatory cytokines of $\mathrm{T}$ cell are involved in the pathogenesis of childhood nephrotic syndrome. In addition, $\mathrm{B}$ cells can enhance $\mathrm{T}$-cell responses by producing antibodies, stimulatory cytokines, producing inflammatory responses, thereby accelerating and aggravating the occurrence and 
development of NS (18). RTX is a novel therapeutic approach to the clinical management of NS, which induces cell apoptosis by binding to the CD20 membrane antigen in both normal and malignant B cells $(19,20)$. However, there are also studies that propose NS is treatable by podocyte-specific expression of SMPDL3b in RTX therapy (21).

RTX showed an advantage in the complete remission rate, which is consistent with previous related research findings. A study analyzed 33 patients of childhood SDNS treatment with RTX, and the remission rates were $48.5 \%$ after 6 months, among which most were sustained remission (15 cases, 94\%) (22). Prytula et al. reported that $\sim 66 \%$ of patients achieved complete or partial remission after RTX therapy (23). Another study reported that $20(80 \%)$ of 25 SDNS patients achieved complete remission after receiving RTX treatment, and one of the remaining cases has recurred after withdrawal of RTX (24). Indeed, these data showed that RTX treatment can be effective in achieving complete remission.

RTX could effectively improve eGFR level and serum albumin level in patients with childhood SDNS. Some studies (11, 12, 25) have also confirmed the long-term benefits or risks of the use of this new type of drug compared with the usual immunosuppressive agents in the past. Therefore, RTX can be used to improve the serum albumin and eGFR levels of patients, which facilitate the remission and recovery of the disease.

However, RTX neither significantly decreased the levels of serum creatinine nor significantly reduced the occurrence of proteinuria, and the results were inconsistent with data published now. The discrepancy may be due to the following reasons. First, the differences of pathological types existed in different patients, which varied in their response to RTX treatment. Second, the usage and dosage of RTX were not uniform in the included study, and this may also have an impact on the results. Third, only one study presented the data on serum creatinine among all the included studies, so the number of included cases was small and therefore not representative.

RTX were well-tolerated in most patients of NS, with infusion reactions as the most frequently reported adverse effect, and the incidence was $5-53 \%$ (26). Generally, slowing down the rate of infusion or applying antihistamines can alleviate it, and very few children will have severe allergic reactions (27). In this study, RTX treatment did not cause a significant reduction on the incidence of adverse events and did not show an advantage on safety (11-13). However, when some patients cannot tolerate immunosuppressive agents or develop drug resistance to these immunosuppressive agents, RTX treatment may lead to a positive curative effect (5).

However, there are still a few limitations in this study. First, studies included in our meta-analysis enrolled patients from different regions or countries, with different symptoms, and there are some basic characteristic differences among these patients, in addition, the follow-up duration of these studies was not unified; all of these factors may result in some of the heterogeneity in some of our results. Second, only six RCTs and one retrospective comparative control study were included in the meta-analysis; the number was small and with insufficient clinical evidence, which may result in some statistical bias or error and could reduce the evaluation power. Third, there were different rituximab therapy regimens used in the included studies, while both rituximab dose and maintenance immunosuppression have important effects on the treatment outcomes (28), so it may have had an impact on our analysis results. Fourth, studies included in our meta-analysis had different control groups, which might influence the results of our analysis. Fifth, the number of included cases was relatively small and thus may be underrepresented in the study sample. In addition, RTX treatment is a high-cost therapy, but the relationship between the costs and efficacy of this drug did not reflect in these included studies. Thus, further studies are needed to refine these issues.

\section{CONCLUSIONS}

In conclusion, RTX can be considered a safe and efficient alternative therapy for childhood SDNS. Steroid achieves remission, while RTX plays a role in SDNS by maintaining remission, avoiding relapse, and avoiding further steroid therapy. RTX not only has more advantages in complete remission rate than other immune suppressants but also has ameliorative effects on eGFR and serum albumin. However, the safety and long-term efficacy of RTX have not been fully evaluated, therefore future studies with higher quality, larger sample sizes, and longer durations of follow-up are needed to address this question.

\section{DATA AVAILABILITY STATEMENT}

The original contributions presented in the study are included in the article/supplementary material, further inquiries can be directed to the corresponding author/s.

\section{AUTHOR CONTRIBUTIONS}

SL: conceptualization, writing (original draft), methodology, and software. CG: writing (review and editing). ZL: formal analysis. HL: investigation and data curation. ZF: investigation and data curation. YD: writing (review and editing), supervision, and funding acquisition. All authors contributed to the article and approved the submitted version.

\section{FUNDING}

This research was supported by Shanghai Municipal Key Clinical Specialty (No. shslczdzk04201), the Second Batch of Scientific Research Projects of Construction of National TCM Clinical Research Base (No. JDZX2015097), and the Scholar of Longhua Hospital, Shanghai University of Traditional Chinese Medicine (No. LYTD-85). 


\section{REFERENCES}

1. Dolcemascolo V, Vivarelli M, Colucci M, Diomedi-Camassei F, Piras R, Alberti M, et al. Nephrotic-range proteinuria and peripheral edema in a child: not only idiopathic nephrotic syndrome. Case Rep Nephrol Dialysis. (2016) 6:120-7. doi: 10.1159/000449423

2. Eddy AA, Symons JM. Nephrotic syndrome in childhood. Lancet. (2003) 362:629-39. doi: 10.1016/S0140-6736(03)14184-0

3. Wu HM, Tang JL, Cao L, Sha ZH, Li Y. Interventions for preventing infection in nephrotic syndrome. Cochrane Database Syst Rev. (2012) 2012:Cd003964. doi: 10.1002/14651858.CD003964.pub3

4. Arif MK, Arif M, Amjad N. A histopathological outlook on nephrotic syndrome: a pediatric perspective. Indian J Nephrol. (2016) 26:18891. doi: 10.4103/0971-4065.159555

5. Sinha A, Bagga A. Rituximab therapy in nephrotic syndrome: implications for patients' management. Nat Rev Nephrol. (2013) 9:154-69. doi: 10.1038/nrneph.2012.289

6. Grenda R, Jarmuzek W, Rubik J, Piatosa B, Prokurat S. Rituximab is not a "magic drug" in post-transplant recurrence of nephrotic syndrome. Eur J Pediatr. (2016) 175:1133-37. doi: 10.1007/s00431-016-2747-1

7. Safdar OY, Aboualhameael A, Kari JA. Rituximab for troublesome cases of childhood nephrotic syndrome. World J Clin Pediatr. (2014) 3:6975. doi: 10.5409/wjcp.v3.i4.69

8. Ashikaga E, Uda S, Kamata K, Shikida Y, Inoue T, Kuno Y, et al. Single low-dose rituximab for the treatment of steroid-resistant nephrotic syndrome with acute kidney injury. CEN Case Rep. (2016) 5:5660. doi: 10.1007/s13730-015-0199-5

9. Iijima K, Sako M, Nozu K. Rituximab for nephrotic syndrome in children. Clin Exp Nephrol. (2017) 21:193-202. doi: 10.1007/s10157-016-1313-5

10. Moher D, Liberati A, Tetzlaff J, Altman DG. Preferred reporting items for systematic reviews and meta-analyses: the PRISMA statement. PLoS Med. (2009) 6:e1000097. doi: 10.1371/journal.pmed. 1000097

11. Ahn YH, Kim SH, Han KH, Choi HJ, Cho H, Lee JW, et al. Efficacy and safety of rituximab in childhood-onset, difficult-to-treat nephrotic syndrome: a multicenter open-label trial in Korea. Medicine. (2018) 97:e13157. doi: 10.1097/MD.0000000000013157

12. Basu B, Sander A, Roy B, Preussler S, Barua S, Mahapatra TK, et al. Efficacy of rituximab vs tacrolimus in pediatric corticosteroid-dependent nephrotic syndrome: a randomized clinical trial. JAMA Pediatr. (2018) 172:757-64. doi: 10.1001/jamapediatrics.2018.1323

13. Iijima K, Sako M, Nozu K, Mori R, Tuchida N, Kamei K, et al. Rituximab for childhood-onset, complicated, frequently relapsing nephrotic syndrome or steroid-dependent nephrotic syndrome: a multicentre, doubleblind, randomised, placebo-controlled trial. Lancet. (2014) 384:127381. doi: 10.1016/S0140-6736(14)60541-9

14. Ravani P, Magnasco A, Edefonti A, Murer L, Rossi R, Ghio L, et al. Shortterm effects of rituximab in children with steroid- and calcineurin-dependent nephrotic syndrome: a randomized controlled trial. Clin J Am Soc Nephrol. (2011) 6:1308-15. doi: 10.2215/CJN.09421010

15. Ravani P, Lugani F, Pisani I, Bodria M, Piaggio G, Bartolomeo D, et al. Rituximab for very low dose steroid-dependent nephrotic syndrome in children: a randomized controlled study. Pediatr Nephrol. (2020) 35:143744. doi: 10.1007/s00467-020-04540-4

16. Solomon N, Lalayiannis AD. Rituximab is more effective than tacrolimus in steroid-dependent nephrotic syndrome. Arch Dis Child Educ Pract Ed. (2019) 104:279-80. doi: 10.1136/archdischild-2018-316537

17. Sinha A, Bagga A, Gulati A, Hari P. Short-term efficacy of rituximab versus tacrolimus in steroid-dependent nephrotic syndrome. Pediatr Nephrol. (2012) 27:235-41. doi: 10.1007/s00467-011-1997-4
18. Kim AH, Chung JJ, Akilesh S, Koziell A, Jain S, Hodgin JB, et al. B cell-derived IL-4 acts on podocytes to induce proteinuria and foot process effacement. JCI Insight. (2017) 2:e81836. doi: 10.1172/jci.insight.81836

19. Kemper MJ, Meyer-Jark T, Lilova M, Müller-Wiefel DE. Combined T- and B-cell activation in childhood steroid-sensitive nephrotic syndrome. Clin Nephrol. (2003) 60:242-7. doi: 10.5414/CNP60242

20. Abdel-Hafez M, Shimada M, Lee PY, Johnson RJ, Garin EH. Idiopathic nephrotic syndrome and atopy: is there a common link? Am J Kidney Dis. (2009) 54:945-53. doi: 10.1053/j.ajkd.2009.03.019

21. Fornoni A, Sageshima J, Wei C, Merscher-Gomez S, AguillonPrada R, Jauregui AN, et al. Rituximab targets podocytes in recurrent focal segmental glomerulosclerosis. Sci Transl Med. (2011) 3:85ra46. doi: 10.1126/scitranslmed.3002231

22. Gulati A, Sinha A, Jordan SC, Hari P, Dinda AK, Sharma S, et al. Efficacy and safety of treatment with rituximab for difficult steroid-resistant and dependent nephrotic syndrome: multicentric report. Clin J Am Soc Nephrol. (2010) 5:2207-12. doi: 10.2215/CJN.03470410

23. Prytuła A, Ijijma K, Kamei K, Geary D, Gottlich E, Majeed A, et al. Rituximab in refractory nephrotic syndrome. Pediatr Nephrol. (2010) 25:4618. doi: 10.1007/s00467-009-1376-6

24. Iwabuchi $\mathrm{Y}$, Takei $\mathrm{T}$, Moriyama $\mathrm{T}$, Itabashi $\mathrm{M}$, Nitta K. Long-term prognosis of adult patients with steroid-dependent minimal change nephrotic syndrome following rituximab treatment. Med. (2014) 93:e300. doi: 10.1097/MD.0000000000000300

25. Iwabuchi Y, Miyabe Y, Makabe S, Nakano M, Manabe S, Karasawa K, et al. Comparison of the response of frequently relapsing steroiddependent minimal change nephrotic syndrome to rituximab therapy between childhood-onset and adult-onset disease. Medicine. (2018) 97:e12704. doi: 10.1097/MD.0000000000012704

26. Bonanni A, Calatroni M, D’Alessandro M, Signa S, Bertelli E, Cioni M, et al. Adverse events linked with the use of chimeric and humanized antiCD20 antibodies in children with idiopathic nephrotic syndrome. Br J Clin Pharmacol. (2018) 84:1238-49. doi: 10.1111/bcp.13548

27. Kamei $K$, Ogura $M$, Sato $M$, Ito $S$, Ishikura $K$. Infusion reactions associated with rituximab treatment for childhoodonset complicated nephrotic syndrome. Pediatr Nephrol. (2018) 33:1013-8. doi: 10.1007/s00467-018-3900-z

28. Chan EY, Webb H, Yu E, Ghiggeri GM, Kemper MJ, Ma AL, et al. Both the rituximab dose and maintenance immunosuppression in steroiddependent/frequently-relapsing nephrotic syndrome have important effects on outcomes. Kidney Int. (2020) 97:393-401. doi: 10.1016/j.kint.2019.09.033

Conflict of Interest: The authors declare that the research was conducted in the absence of any commercial or financial relationships that could be construed as a potential conflict of interest.

Publisher's Note: All claims expressed in this article are solely those of the authors and do not necessarily represent those of their affiliated organizations, or those of the publisher, the editors and the reviewers. Any product that may be evaluated in this article, or claim that may be made by its manufacturer, is not guaranteed or endorsed by the publisher.

Copyright (c) $2021 \mathrm{Liu}, \mathrm{Gui}, \mathrm{Lu}, \mathrm{Li}, \mathrm{Fu}$ and Deng. This is an open-access article distributed under the terms of the Creative Commons Attribution License (CC BY). The use, distribution or reproduction in other forums is permitted, provided the original author(s) and the copyright owner(s) are credited and that the original publication in this journal is cited, in accordance with accepted academic practice. No use, distribution or reproduction is permitted which does not comply with these terms. 